DOI: 10.19195/0137-1150.163.37

\author{
JANA KOLÁŘOVÁ \\ Univerzita Palackého v Olomouci, Republika Czeska \\ jana.kolarova@upol.cz
}

\title{
Obraz stáŕí v moralitách raného novověku
}

Ve svém prríspěvku bych se chtěla zastavit u obrazu stáŕí v českojazyčných moralizujících spisech raného novověku, konkrétně v době pozdního humanismu, tedy ve druhé polovině 16 . století a první čtvrtině století 17. Dovolím si na počátek citovat z úvahy Miloše Havelky nazvané $O$ aktualitě stáŕí, která otevírá sborník příspěvků na téma stáŕí v 19. století: „Stáří není jen biologické určení, ale také nebo především kulturně konstruovaný pojem; jeho obsah se mění v různých dobách." 'Stařecký věk je spojen s určitými kulturními stereotypy, jako jsou např. naplnění života, věk moudrosti, smiření a přijetí (pozitivní), ale též negativními (tvrdohlavost, nevrlost, předsudky, konzervativnost, samota, vykořeněnost apod.). ${ }^{2}$ Pohlédneme-li do minulosti prizmatem historiků každodennosti, uvědomíme si, že dožít se stáří nebylo v dobách minulých zdaleka pravidlem, zatímco dnes díky pokroku $\mathrm{v}$ hygieně a medicíně zažije nebo zažívá převážná většina populace stáří na vlastní kůži. Pokud člověk raného novověku přežil dětství, zvyšovala se jeho naděje na dosažení stáríi, avšak přesto je třeba si uvědomit fakt, že v předindustriální době tvořili staří lidé pouze malou část společnosti, přičemž lidí starších šedesáti let nebylo více než deset procent. ${ }^{3}$

Vymezení stařeckého věku, tedy jeho počátku, bylo předmětem úvah již od antiky. Hippokratés hovoří jako o předělu o padesátém šestém roce věku člověka, Aristoteles považuje za začátek stařeckého věku padesátý rok. ${ }^{4}$ Za staré byli považováni lidé, kteří již kvůli úbytku fyzických sil nemohli pracovat, neklamnými signály pak byly fyzické příznaky stáŕí jako vrásky, šedé vlasy, vypadávání zu-

${ }^{1}$ M. Havelka, O aktualitě stáři, [w:] Vetché stáři, nebo zralý věk moudrosti? Sborník prrispěvků z 28. ročníku sympozia k problematice 19. století, zprac. Z. Hojda, M. Ottlová, R. Prahl, Praha 2009, s. 17.

2 Ibidem, s. 8.

${ }^{3}$ M. Lenderová a kol., Žena v českých zemích od středověku do 20. století, Praha 2009, s. 154.

${ }^{4}$ Ibidem. 
bů apod. Martin Nodl připomíná, že v období středověku byla hlavním zdrojem představ o stařeckém věku Bible, zejména Starý zákon. „Nadpřirozená” dlouhověkost prvních lidí (např. Adam se dožil 930 let, jeho syn Šét - 920) se postupně zkracovala (Abraham žil již jen 175 let, Josef - 110 let), což středověký člověk chápal jako přirozený důsledek božího hněvu. ${ }^{5}$ Ani raný novověk, a moralizující spisy zejména, se biblického inspiračního zdroje nevzdával. Jednou z nejcitovanějších biblických knih v parenetických typech textů je bezpochyby starozákonní kniha Kazatel, kde čteme popis stařeckého věku spojený s nabádavými důrazy:

Pamatuj na svého Stvořitele ve dnech svého jinošství, než nastanou zlé dny a než se dostaví léta, o kterých řekneš: „Nemám v nich zalíbení,” než se zatmí slunce a světlo, měsíc, hvězdy, a vrátí se po dešti mraky. V ten den se začnou třást strážcové domu a mužové zdatní se zkřiví a mlečky nechají práce a bude jich málo, a ty, kdo hledí z oken, obestře temnota, a zavrou se dveře do ulice a ztiší se hlas mlýnku a vstávat se bude za šveholu ptactva a všechny zpěvy budou znít přidušeně. A člověk se bude bát výšek a úrazů na cestě; a rozkvete mandloň a těžce se povleče kobylka a kapara ztratí účinnost. Člověk se vydá do svého věčného domu a ulicí budou obcházet ti, kdo naříkají nad mrtvými. (Kazatel 12,1-5)

Stylově a tematicky nejvýraznějším okruhem textů, v nichž se v době předbělohorské téma stáří objevuje, jsou morality komponované jako sled jednotlivých fází lidského života, často prostřednictvím alegorického rámce (typ tzv. theatrum mundi). V českém prostředí máme takových textů hned několik; vesměs vznikly v poměrně krátkém časovém úseku na samém počátku 17. století. Jedná se o spis Bartoloměje Paprockého z Hlohol Třinácte tabuli věku lidského (1601), Tobiáše Mouřenína z Litomyšle Věk člověka (1604) a Nathanaela Vodňanského z Uračova Theatrum mundi minoris (1605). Struktura tohoto typu děl sahá až do antiky, odkud pochází schémata založená na číslech tři, čtyři nebo sedm. Svatý Augustin dělí lidský život na sedm etap, z nichž ta poslední, tedy stáří, začíná v šedesáti letech. Isidor ze Sevilly členil období lidského života na infantia (do sedmi let), pueritia (do čtrnácti let), adulescentia (do osmadvaceti), iuventus (do padesáti), do sedmdesáti trvá gravitas, a až v poslední fázi lidského života, tedy po sedmdesátém roce, nastupuje stárí, senilitas. ${ }^{6} \mathrm{~V}$ hippokratovské medicíně odpovídá chronologickým schématům nauka o čtyřech tělesných tekutinách — mladé dítě je vlhké a teplé, chlapec je teplý a suchý, dospělý muž suchý, a chladný, starý chladný a vlhký. Toto členění se však týkalo primárně mužského světa, zatímco

${ }^{5}$ M. Nodl, Stář́i v pozdním středověku, „Souvislosti” 1997, č. 2, s. 7-28. Teolog a biblista Martin Prudký k této problematice mj. uvádí, že „,číselné údaje jsou v biblickém podání daných rodopisných látek prvkem nejvíce labilním a variabilním. Struktura rodopisu je pro tradici pevnou formou; v ní jsou primárně důležitá jména, pak celkové souhledy velkých ér (celkové součty) a v jejich rámci pak vnitřní vztahy relativní chronologie. Údaje o jednotlivých postavách jsou tomu podřízeny a tradice, jak ji známe, právě s těmito údaji důmyslně a velmi dynamicky pracuje." Viz M. Prudký, Časové údaje v Bibli nejsou fakta, ale symboly, http://www.etf.cuni.cz/ prudky/mptexty/99LNcasove_udaje.html [12.4.2015]

${ }^{6}$ M. Nodl, op. cit., s. 68. 
svět ženy byl určován jejími biologickými rolemi, tj. dobou dětství, plodnosti a odkvětu. ${ }^{7}$

Zaměřme se nyní na analýzu toho, jak jednotliví autoři ztvárňují období stáří a stereotypy s ním spojené. Bartoloměj Paprocký rozděluje lidský život do třinácti období (tabulí), prričemž ke staršímu věku se dostává v tabuli osmé, v níž se mluví o věku padesáti let. $\mathrm{V}$ této a další části (šedesátiletý muž) zdůrazňuje Paprocký především potřebu vyrovnanosti a životní moudrosti, a to i v případě, že se člověku nepodařilo dosáhnout všeho, co chtěl. V tomto věku by již člověk měl vědět, že Štěstěna je vrtkavá, a proto se má každý spokojit s málem. V šedesáti letech již „,touha pozemská je vyschlá” 8 a jedna z lidských opor, totiž „,milost světa tohoto, i všelijakých rozkoší jeho, kteráž jej k zemským věcem vodila, pokleslá jest a uvadlá." "C Clověk by měl litovat hříchů mládí a usilovat o zbožné prožití času, který mu ještě zbývá. V rozporu se skutečností, že lidé se dožívali v průměru mnohem nižšího věku než dnes, Paprocký svoje pojednání zakončuje až po devadesátém roce věku, kdy následuje předposlední, dvanáctá tabule, „kteráž jest poslední částka života." ${ }^{10}$ Poslední, třináctá tabule, narušuje strukturu předchozího textu, je mnohem rozsáhlejší, vnitřně dále diferencovaná, obsahuje množství biblických citátů a exempel a je jakýmsi rozjímáním o smrti, pomíjivosti života a životě věčném.

Celkové ladění Paprockého spisu je spíše pesimistické; dílo je nabádavé, parenetické, takže autor píše o tom, co by mělo být a jak by se měl starý člověk chovat, čímž implicitně říká, že se to často neděje. Autor popisuje negativní stereotypy stáŕí jako prchlivost, nesmířenost s osudem, dětinskost, nechut' přijmout svůj věk a s tím i blížící se smrt, nedostatek zbožnosti. Jakýmsi toposem tohoto typu moralit bývá alespoň jedna pasáž, v níž se mluví o tělesném chátrání, a to s expresivitou až barokní, jež má za cíl citově zasáhnout tam, kde by snad racionální argumenty selhaly:

[...] v čas ten, když již všecko tělo starostí vadne, když oči zrak potracují, uši sluchu nemají, když tvář bledne, zuby hnijí, kůže se krčí, ústa zapáchají, prsy duch volně nevypouští, kolena se třesou, nohy tížnost zdržeti těla nemohou. Chtěj tehdy neb nechtěj, musíš zanechati věci mladosti přináležející, musíš opustiti freje, žerty i hry, nimiž když se obíráš, morti ludens delicias facis, jakž dí Seneka, nelze jináče učiniti, učinil tvůj věk konec všeliké radosti mladým zvyklé, a léta všem zbytečným marnostem cestu zastoupily. ${ }^{11}$

Duchovní hra (zřejmě však nikdy jevištně nerealizovaná) Tobiáše Mouřenína z Litomyšle Věk člověka přivádí na scénu postupně zástupce jednotlivých desetiletí lidského života, počínaje desetiletým chlapcem. Ke každému mluví poustev-

${ }^{7}$ Ibidem, s. 69.

${ }^{8}$ B. Paprocký z Hlohol, Třinácte tabuli věku lidského krátce sepsaných etc., Praha 1601, s. Diiir.

${ }^{9}$ Ibidem, s. Diiir.

${ }^{10}$ Ibidem, s. Ev.

${ }^{11}$ Ibidem. 
ník, který ho nabádá k ctnosti, ale jednotliví protagonisté neoblomně setrvávají v hříchu. Padesátiletý a šedesátiletý muž je prohnaný a lakotný, sedmdesátník je závistivý a zlostný, osmdesátník vzpomíná na mladické freje a přiznává, že „předcet' jsou mi mladice velmi milé / rovně jako když jsem měl lét třidceti," ${ }^{12}$ ba dokonce říká: ,[...]když u pěkných mladic sedím, / ještě k smíchu něco vyvesti hledím, / někdy některé i za ňadra sáhnu [...]"13 Devadesátiletý muž již pouze naříká nad bídami stařeckého věku a přeje si smrt, avšak teprve stoletý se kaje za to, jak nemravný byl jeho dosavadní život. Mouřenínovo dílo má ještě varovnější vyznění než Paprockého spis, nebot' pozdní lítost stoletého starce již nezabrání tomu, aby jej smrt bez slitování neuchvátila. Obšírná promluva smrti je postavena především na typickém toposu omnibus est moriendum. Do hry ještě krátce vstoupí postava d'ábla, který si odnáší hř́ššnou duši, a poté následuje závěrečný passus poustevníka, jenž varuje posluchače (čtenáře) před celkovým úpadkem morálky. „Závěrek” celé hry je pak obecným zamyšlením nad neutěšeným stavem společnosti, $v$ jehož důsledku Bůh sesílá na lidi řadu trestů, jako je zejména turecké ohrožení Evropy. Autor se zde přibližuje až apokalyptickým polohám, když mluví o blízkosti soudného dne.

Také Mouřenín, podobně jako Paprocký, ukončuje přehled jednotlivých etap lidského života až stoletým starcem. Tato praxe byla zřejmě vyvolána potřebou jisté proporcionality a uspořádané struktury literárního obrazu jednotlivých lidských časů. Věk sto let reprezentuje symbolické dovršení, nejzazší dosažitelnou metu člověka.

Hana Bočková, autorka studie $\mathrm{k}$ edici spisu Theatrum mundi minoris Nathanaela Vodňanského, charakterizuje strukturu díla takto:

Nejprve je pojednáno o fázích lidského života od početí, narození až do smrti, pak v devíti kapitolách o nejvýznamnějších lidských stavech a povoláních. Oba způsoby pojednání o člověku se nevyskytují spolu $v$ jednom textu př́liš často. [...] Theatrum rezignuje na detail a úplnost výčtu svých stavů a povolání, ani počtem lidských věků nedosahuje Paprockého třináctky, jeho cesta např́íc lidským životem a společenskou strukturou však současně podává obraz plastičtější. ${ }^{14}$

Vodňanský ve své adaptaci francouzské předlohy přejímá jednak alegorii světa jako divadla, jednak metaforické členění jednotlivých životních fází podle staveb, v nichž se v antice odehrávaly různé typy představení. Stařeckému věku odpovídá xystus, tedy zimní zahrada, určená k procházkám. Jestliže dvě přechozí díla měla pesimistické vyznění, pak Vodňanského spis představuje lidský život v perspektivě takřka beznadějné. Stáří je stavem tak děsivým a odpudivým, že smrt se jeví jako vysvobození: ,starost člověka na tomto světě nic jiného není než hluboký a smrad-

12 T. Mouřenín z Litomyšle, Věk člověka, [w:] Veršovaná tvorba, zprac. M. Kopecký, Praha 1995, s. 69.

13 Ibidem, s. 70.

${ }^{14}$ H. Bočková, Theatrum mundi minoris jako svědectví o člověku na sklonku jedné epochy, [w:] Nathanael Vodňanskýz Uračova, Theatrum mundi minoris, zprac. H. Bočková, J. Matl, Brno 2001, s. 285. 
lavý trativod, všelikými nečistotami a neduhy života našeho naplněný ${ }^{15}$." Nechybí řada expresivních popisů chátrajícího těla a duše, slovem: po padesátém roce věku je podle názoru autora lépe zemřít než snášet to, co staroba přináší.

V jistém kontrastu s výrazně negativním obrazem stáří ve výše uvedených dílech stojí spis, jenž se na rozdíl od nich věnuje tomuto období výhradně a je zaměřen pouze na něj. Jedná se o dílo kalvínského pastora Havla Žalanského Phaëtona Kniha o starosti aneb věku sešlém a šedivém (1610). Strukturou se sice zcela podobá předchozím pojednáním (kombinatorní psaní v podobě hojných citátů českých i latinských, parafrází, exempel), avšak soustředěnost na jediné téma umožňuje autorovi mnohem komplexnější pohled na problematiku. Nejen člověk stárne, ale celé stvoření je poddáno zániku, jedná se o nevyhnutelný důsledek prvotního hříchu a porušení rajské přirozenosti. Autor odkazuje na autority, jako je Galenos či Plinius, a celkové pojetí spisu se pohybuje na rozhraní díla naukového a moralizujícího. Žalanský nabádá ke stř́ídmosti v jídle, pití i tělesných rozkoších, které přivozují brzké stárnutí16 a zařazuje kapitolu O bídě, strasti, vadách, mdlobách a mnohém nepohodli věku sešlého. Mnohem více prostoru však Žalanský věnuje argumentům proti všeobecně rozšířeným stereotypům o stáří jako věku plném utrpení a blízkosti smrti. Namítá, že vše uvedené lze vztáhnout i na mladý věk; mladí lidé jsou častěji nemocní, umírají v mnohem větších mukách, sužují je nespočetné žádosti těla i duše, ohrožují je nebezpečí, jimž se starci již vyhnou (např. nutnost bojovat ve válce). Tělesná slabost znamená větší odkázanost na Krista a delšś věk dává naději, že se člověk dožije lepších časů, kdy ,jasné světlo pravdy Boží všudy se zastkví, a rozkošné lilium Jeho evangelium ve vší naší vlasti kvésti bude."17 Stáří a moudrost prospívá obci, která si do svých rad volí moudré starce. Již názvy kapitol, jako např̀. Jaká důstojnost, sláva a poctivost jest věku starého, vši cti a chvály hodného, a které dobré věci jemu obzvláštně přisluší, naznačují, že vedle moralizujících důrazů je autorův př́stup též apologetický a směřuje ke konstruování ideálu starého člověka, jenž není nedosažitelný. Toto pojetí s sebou nese pochopitelně jiné antické i biblické odkazy a odlišná exempla. ${ }^{18}$ Ideálem starce je biblický Simeon, jedním z odstrašujících př́íkladů naopak Šalamoun, jenž k stáru propadl špatnosti. ${ }^{19}$ Žalanského dílo směřuje čtenáře $\mathrm{k}$ tomu, aby přijímal věci s poko-

15 N. Vodňanský z Uračova, Theatrum mundi minoris, zprac. H. Bočková, J. Matl, Brno 2001, s. 195.

16 „Odkudž i životčichové, kteří se často scházejí, brzy stárnou a umírají, jako dlouho živi nebývají chlípní vrabci." (H. Žalanský Phaëton, Kniha o starosti aneb věku sešlém a šedivém, Praha 1610, s. 7).

17 Ibidem, s. 14.

${ }^{18} \mathrm{Z}$ antických autorů je hojně citován Ciceronův spis De senectute a též Ovidius nebo Juvenalis.

19 Žalanský objasňuje např. otázku, jak je možné, že se bibličtí praotcové před potopou dožívali tak vysokého věku. Vysvětluje, že se jedná o figuru plnosti života, „tisíc let má obraz dokonalosti” (H. Žalanský Phaëton, op. cit., s. 52). 
rou a takřka stoickým klidem postaveným na hlubokém a zbožném přesvědčení, že Bůh má vše ve svých rukou.

Za zmínku na tomto místě stojí, že autoři moralit usilovali o vytvoření textů, jež budou disponovat nejen obsahovými, ale též formálními kvalitami. Ačkoli moralizující spisy jsou většinou považovány spíše za inklinující k naukové literatuře, která se projevům literárnosti postupně vzdalovala, přesto $\mathrm{v}$ nich nalezneme celou řadu prostředků, jimiž autoři své texty ozvlášňovali a činili je čtenářsky přitažlivějšími. Na prvním místě se jedná nepochybně o exempla, bez nichž si tento typ děl takřka nelze představit. Vedle narativů v exemplární funkci však nalezneme také četná metaforická přirovnání či paralelismy, jež zvyšují účinek textu na čtenáře (viz nap̌r. gnómy ,jest krásné jaro, ale užitečnější podzimek; nový kmen hodnější, ale kmen starší víno lepší vynášš”, či přirovnání ,jako v sudích a džbánech rmut a kvasnice dole při dnu se usazují, tak náklonku života mnohé strasti se přidrží" nebo metaforický obraz ,již jednu nohu v království Božím mají, již vůní sladkých rozkoší nebeského ráje cítí. V té věci nad starce co štastnějšího?"20 apod.).

$\mathrm{V}$ druhé části př́íspěvku bychom se chtěli ještě alespoň stručně zastavit u specifik ženského stáŕí a jeho literárního ztvárnění v moralizujících dílech pozdního humanismu.

Raněnovověká literatura odlišila při definování ideálu feminity stav panenský, manželský a vdovský. ${ }^{21}$ Největší pozornost byla věnována stavu panenskému; preskriptivních spisů vztahujících se $\mathrm{k}$ vdovskému stavu bylo méně. Je ovšem nutné si uvědomit, že vdova nemusela být nutně starou ženou. ${ }^{22}$

Obraz stařeny $\mathrm{v}$ moralizujících textech byl vesměs mnohem expresivnější a odpudivější než zobrazení starce. Jak poukazuje Milena Lenderová, stařeny by-

${ }^{20}$ Ibidem, s. 29, 35, 30.

${ }^{21}$ M. Lenderová a kol., op. cit., s. 52.

22 Pokud jde o konstruování obrazu staré ženy, tomuto problému věnovaly pozornost např. editorky Lucie Storchová a Jana Ratajová ve studiích k edici Nádoby mdlé, hlavy nemajicí: diskursy panenství a vdovství v české literatuře raného novověku (Praha 2008), jež obsahuje mj. preskriptivní spis Jana Hertvicia Pražského Vdovství křest’anské z roku 1619. Dalším zdrojem informací, o nějž se dnes literární historik může opřít, je řada odborných pojednání z dějin každodennosti (např. práce historičky Mileny Lenderové, jež byly inspirací i našim úvahám). Není však zdaleka možné na malé ploše př́spěvku pojednat všechny aspekty tohoto tématu. $Z$ hlediska tematiky stáŕí je mj. zajímavé zobrazení nerovných sňatků, tj. takových, v nichž jeden z páru je výrazně starší než druhý. (Viz obrazy malírự, jako je Lucas Cranach starší nebo Quentin Massys, nazvané Nerovný pár). Přestože zejména sňatky starších mužů s výrazně mladšími ženami byly ve starších obdobích poměrně běžné, věková disproporce podněcovala satirické ztvárnění, vzbuzující posměch. Lenderová cituje např̀. Mikuláše Dačického z Heslova, jenž si k úmrtí kutnohorského měštana Vodičky do svých pamětí zaznamenal: „Václav Vodička, jenž byv mistrem školním, měl k manželství Dorotu Čechtickou, vdovu starou, již pro peníze - jsa mlád pojal, ale při těch penězích žádné rozkoše a zvůle neužil." (M. Lenderová a kol., op. cit., s. 145). Představa starce — chlípníka, toužícího po mladičké ženě, má prastaré kořeny sahající $\mathrm{k}$ biblickému deuterokanonickému př́íběhu o ctnostné Zuzaně křivě obviněné právě takovými vilnými muži, pro něž existuje staročeské apelativum zuzaník. Rozmanitou literaturu k této problematice shrnuje např. M. Nodl, op. cit., s. 27-28. 
ly v průběhu celých starších dějin často ztotožňovány s čarodějnicemi. ${ }^{23} \mathrm{Již} \mathrm{ve}$ středověké literatuře se objevuje obraz „baby”, která je horší než d'ábel, naplňujíc tak rčení, že kam čert nemůže, pošle babu (viz např. skladbu Desatero kázanie božie nebo Olomoucké povídky, obsahující prríběh „o jedné babě čarodějné, jenž bieše horšie než črt", která dokázala rozklížit dobré manželství a přivést manžela k vraždě své ženy ze žárlivosti). Z raněnovověkých autorů moralit věnuje největší pozornost tomuto typu žen patrně Šimon Lomnický z Budče, jenž píše (zejména v Kupidově střele, 1590) o tzv. babách svodnicích, které za peníze dokážou 1stí svést počestnou mladou dívku na scestí. Sám Lomnický odkazuje ještě na jednoho ze soudobých moralistů, který baby svodnice pranýřuje, a to Václava Dobřenského a jím vydaný spis Pramen vody živé (1581). Dobřenský v uvedené souvislosti píše např. toto: „Jazyk baby svodné jest plný nepravosti a jedu smrtelného, zapálen jsa od ohně pekelného, kterýmžto jazykem d’ábel rovně jako kovář měchy oheň rozněcuje..."24

Jak je pro strukturu Lomnického děl obvyklé, autor prokládá své texty hojnými exemply, dokládajícími d’ábelskou prohnanost a amorálnost zmíněných stařen. Mezi těmito narativy nalezneme i vyprávění o babě „horší než čert” z výše zmíněných Olomouckých povídek. S jak velkou mírou odporu jsou stařeny Lomnickým popisovány, o tom svědčí např. tento citát:

Když jest kurvou stará žena, / nestydatá psice, fena, / ta všecken statek rozptýlí, / rozdá, aby se s ní psili. / Není větší ohavnosti, / mrzuté nešlechetnosti, / jako když ta baba shnilá, / chtíc býti též ještě milá, / jelena za rohy drží, / an to čerta v pekle mrzí. / Neb jednou, když při tom čert byl, / pfi, pfi, pfi, takhle na to plil. / Kdyby právům průchod dali, / živou by ji zahrabali. ${ }^{25}$

Jak píše M. Lenderová, „sám pojem ,stařena‘ (vetula) zněl zlověstně, provázela ho slepota, hluchota nebo zchromlé údy, na nichž se podepsaly úrazy, artróza, revmatismus. K nevábnému obrazu patřilo nečisté tělo, špinavý a potrhaný oděv."26 Jako literární doklad tohoto tvrzení můžeme citovat již zmiňovaného Tobiáše Mouřenína z Litomyšle, jehož spis Ličidlo krásné pannám a paním je adaptací díla Vincenze Portia Schminke für die Jungfrauen und Weiber (1593). Takto se Mouřenín vyslovuje o starých ženách, které se chtějí pomocí líčidel omladit:

Staré ženy a baby ty se šlechtí,

mladým se rovnají, staré bejt nechtí,

z nichž mnohá téměř jako kozel smrdí,

jest co polívka z shnilého vosrdí. ${ }^{27}$

${ }^{23}$ M. Lenderová a kol., op. cit., s. 155.

${ }^{24}$ V. Dobřenský, Pramen vody živé, to jest naučeni a výstraha před cizoložstvem, jenž hasi a dusí hanebný hř́ch všelikého smilstva etc., Praha 1581, f. 99r.

25 J. Krč, Kam d'ábel nemůže, tam ženu pošle (Baba svodnice v exemplech Šimona Lomnického z Budče), „Souvislosti” 1997, č. 2, s. 92.

${ }^{26}$ M. Lenderová a kol., op. cit., s. 156.

27 T. Mouřenín z Litomyšle, Ličidlo krásné pannám a paním, [w:] Veršovaná tvorba, zprac. M. Kopecký, Praha 1995, s. 200. Viz též M. Kopecký, Problematika tvorby Tobiáše Mouřenína, 
Shrneme-li na závěr poznatky našeho stručného exkurzu do pozdně humanistických moralit, můžeme vidět určitý rozdíl mezi okruhem textů, v nichž je stáří ztělesněno prostřednictvím mužských postav, a těch, kde jsou ztvárněny postavy starých žen. První z nich jsou většinou díla, která směřují k obecnému zamyšlení nad pomíjivostí lidského života, nad jeho smyslem, místem člověka v řádu věcí a transcendentálními přesahy lidské existence. Stáŕí přináší nevyhnutelnou blízkost smrti, která je kromě víry v Boha ultimativním imperativem lidské mravnosti, jedním z mála korektivů, jimž se není možné vyhnout. Dodává pádnost morálním nárokům, které texty obsahují. Naproti tomu staré ženy ve spisech figurují spíše jako karikatury, odstrašující př́íklady konkrétního jednání, které nebývá povýšeno do obecné či existenciální roviny.

Období pozdního humanismu se často označuje za konečnou fázi jedné epochy, která předznamenává změnu axiologického systému a vyznačuje se rozkolísaností, nestabilitou, strachem z nejisté budoucnosti. I v našich textech se často tyto životní pocity dostávají s tématem stáŕí či umírání do souvislosti; ostatně není jistě náhodou, že tolik typologicky podobných textů vzniká v tak krátkém časovém rozmezí právě $\mathrm{v}$ této době. Autoři přitom nehovoří vždy jen o stárnutí individua, ale též o „stárnutí světa”, stárnutí času, evokují pocit mundus senescit, známý již ze středověké literatury — svět stárne a blíží se svému zániku (viz až apokalyptické motivy u Tobiáše Mouřenína). Havel Žalanský explicitně uvádí, že svět „pomalu stárne a umdlévá a potracuje prvnější čerstvost” nebo „svět čím dál víc a víc zachází a v horší jde", 28 což dokládá řadou př́íkladů. Snad právě tento pocit $\mathrm{v}$ doznívající renesanci dodal na aktuálnosti literárnímu ztvárnění závěrečných životních fází, období stáří, po němž přichází smrt. Stáří, a s ním spojené memento mori, jež bude ještě intenzivněji prožíváno zejména v nastupujícím baroku, však rovněž připomíná, že smrt může být nejen definitivním koncem, ale také počátkem něčeho nového.

\section{Bibliografie}

Bočková H., Theatrum mundi minoris jako svědectví o člověku na sklonku jedné epochy, [w:] Nathanael Vodňanský z Uračova, Theatrum mundi minoris, zprac. H. Bočková, J. Matl, Brno 2001.

Dobřenský V., Pramen vody živé, to jest naučení a výstraha před cizoložstvem, jenž hasí a dusí hanebný hřich všelikého smilstva etc, Praha 1581.

Havelka M., O aktualitě stárí, [w:] Vetché stáři, nebo zralývěk moudrosti? Sborník př́spěvkủ z 28. ročníku sympozia k problematice 19. století, zprac. Z. Hojda, M. Ottlová, R. Prahl, Praha 2009.

Kopecký M., Problematika tvorby Tobiáše Mouřenína, [w:] Sborník praci filozofické fakulty brněnské univerzity. Studia minora facultatis philosophicae universistatis Brunensis, D 38, Brno 1991.

[w:] Sborník praci filozofické fakulty brněnské univerzity. Studia minora facultatis philosophicae universistatis Brunensis, D 38, Brno 1991, s. 131-139; Č. Zíbrt, Originál spisu Tob. Mouřenína r. 1594 o lićidle, „Časopis českého muzea” 1906, č. 2, s. 371-372.

${ }^{28}$ H. Žalanský Phaëton, op. cit., s. 2 a s. 43.

Slavica Wratislaviensia 163, 2016

(C) for this edition by CNS 
Krč J., Kam d'ábel nemůže, tam ženu pošle (Baba svodnice v exemplech Šimona Lomnického z Budče), „Souvislosti” 1997, č. 2.

Lenderová M. a kol., Žena v českých zemích od středověku do 20. století, Praha 2009.

Mouřenín z Litomyšle T., Věk člověka, [w:] Veršovaná tvorba, zprac. M. Kopecký, Praha 1995.

Nodl M., Stáři v pozdním středověku, „Souvislosti” 1997, č. 2.

Paprocký z Hlohol B., Třinácte tabuli věku lidského krátce sepsaných etc., Praha 1601.

Prudký M., Časové údaje v Bibli nejsou fakta, ale symboly, http://www.etf.cuni.cz/ prudky/mptexty/99LNcasove_udaje.html.

Storchová L., Ratajová, J., Nádoby mdlé, hlavy nemajíci: diskursy panenství a vdovství v české literatuře raného novověku, Praha 2008.

Vodňanský z Uračova N., Theatrum mundi minoris, zprac. H. Bočková, J. Matl, Brno 2001.

Zíbrt Č., Originál spisu Tob. Mouřenína r. 1594 o ličidle, „Časopis českého muzea” 1906, č. 2.

Žalanský Phaëton H., Kniha o starosti aneb věku sešlém a šedivém, Praha 1610.

\section{The representation of age in the moralising books of early modern period}

\section{Summary}

The study focuses on some literary representations of old age and old people in selected works of the early modern period. Those are moralising books written in the years before the Battle of White Mountain (published at the turn of the 17th century), namely Trinácte tabuli věku lidského (The Thirteen Images of Human Life, 1601) by Bartoloměj Paprocký from Hloholy, Věk člověka (The Age of Human, 1604) by Tobiáš Mouřenín from Litomyšl, Theatrum Mundi Minoris (1605) by Nathanael Vodňanský from Uračov, and Kniha o starosti aneb věku sešlém a šedivém (The Book of Misery or the Wretched and Dull Age, 1610) by Havel Žalanský Phaetön.

Keywords: early modern period, human age, moralizing treatises, Bartoloměj Paprocký from Hloholy, Nathanael Vodňanský from Uračov, Havel Žalanský Phaëton

\section{Obraz starości w moralitetach okresu wczesnonowożytnego}

\section{Streszczenie}

Artykuł koncentruje się na niektórych literackich aspektach tematu związanego ze starością i starymi ludźmi w wybranych utworach wczesnego okresu nowożytnego. Chodzi o moralizatorskie spisy z okresu przedbiałogórskiego (wydane na przełomie XVI i XVII wieku), mianowicie o Třinácte tabulí věku lidského (1601) Bartosza Paprockiego, Věk člověka (1604) Tobiasza Mouřenína z Litomyśla, Theatrum mundi minoris (1605) Nathanaela Vodňanskiego z Uračova i Knihu o starosti aneb věku sešlém a šedivém (1610) Havla Žalanskiego Phaëtona.

Słowa kluczowe: wczesna nowożytność, starość, moralitety, Bartoloměj Paprocký z Hlohol, Nathanael Vodňanský z Uračova, Havel Žalanský Phaëton 